\title{
KELAYAKAN NASABAH DALAM PEMBERIAN PEMBIAYAAN KREDIT KEPEMILIKAN RUMAH PADA KANTOR BANK PEMBIAYAAN RAKYAT SYARIAH INVESTAMA MEGA BAKTI MAKASSAR.
}

\author{
Amiruddin K \\ Universitas Islam Negeri Alauddin Makassar \\ uin.amir@yahoo.com
}

\section{Keywords: \\ Customer Feasibility, \\ Feasibility impact, \\ FAST concept}

\section{Kata Kunci:}

Kelayakan Nasabah, dampak Kelayakan, konsep FAST

\section{ABSTRACT}

In assessing the financing application for the marketing department, sharia banks must pay attention to several main principles and analysis related to the overall condition of prospective customers, so as to reduce the level of financing of problematic prospective customers in the world of Islamic banking. This article reviews the feasibility of customer financing in the provision of financing at the office "Bank Pembiayaan Rakyat Syariah IMB Makassar". The approach used is descriptive qualitative' approach. The results show that in analyzing customer financing feasibility in providing financing, "Bank Pembiayaan Rakyat Syariah IMB Makassar" conducts an assessment using the 5C principles of Character, Capacity, Capital, Collateral, and Condition of Economy, and the FAST concepts are Fathanah, Amanah, Shiddiq, and Tabligh. As for the impact of feasibility on financing provision, namely for the Bank, this feasibility has a positive impact because with the feasibility, the Bank can analyze in detail the customer's application. Where as for the customer, this feasibility has a negative impact because to get capital quickly will be hampered by the existence of this feasibility standard.

\begin{tabular}{l} 
ABSTRAK \\
\hline Dalam melakukan penilaian permohonan pembiayaan bank syariah \\
bagian marketing harus memperhatikan beberapa prinsip dan analisis \\
utama yang berkaitan dengan kondisi secara keseluruhan calon \\
nasabah, sehingga bisa mengurangi tingkat pembiayaan bermasalah \\
calon nasabah di dunia perbankan syariah. Artikel ini mengulas \\
tentang kelayakan Pembiayaan nasabah dalam pemberian pembiayaan \\
pada kantor Bank Pembiayaan Rakyat Syariah IMB Makassar. \\
Pendekatan yang digunakan adalah pendekatan kualitatif deskriptif. \\
Hasil yang diperoleh menunjukkan bahwa dalam menganalisis \\
kelayakan Pembiayaan nasabah dalam pemberian pembiayaan, Bank \\
Rakyat Syariah melakukan penilaian dengan menggunakan prinsip 5C \\
yaitu Character, Capacity, Capital, Collateral, and Condition of Economy, dan \\
konsep FAST yaitu Fathanah, Amanah, Shiddiq, dan Tabligh. Adapun \\
dampak kelayakan terhadap pemberian pembiayaan yakni untuk pihak \\
Bank, kelayakan ini berdampak positif karena dengan adanya \\
kelayakan maka pihak Bank dapat menganalisis secara detail \\
permohonan nasabah. Sedangkan untuk pihak nasabah, kelayakan ini \\
berdampak negatif karena untuk mendapatkan modal secara cepat \\
akan terhambat dengan adanya standar kelayakan ini.
\end{tabular}

\section{PENDAHULUAN}

Bank syariah memberikan layanan bebas bunga kepada para nasabahnya. Dalam hal ini, perbankan syariah adalah segala sesuatu yang menyangkut bank syariah dan unit usaha syariah, 
mencakup kelembagaan, kegiatan usaha, serta cara dan proses dalam melakukan kegiatan usahanya. Adapun salah satu produk bank syariah yang sangat membedakan dengan bank konvensional adalah pembiayaan kerja sama usaha. Dalam pembiayaan kerja sama usaha, bank syariah tidak membebani bunga kepada nasabah, akan tetapi ikut serta dalam investasi. Hasil investasi akan diterima dalam bentuk bagi hasil atas usaha yang dijalankan oleh calon nasabah. Dalam pembiayaan kerja sama usaha, dibedakan menjadi dua jenis pembiayaan yaitu pembiayaan Mudharabah dan pembiayaan Musyarakah, (Ascarya, 2013).

Faktor yang menjadi sumber pendapatan utama bank syariah adalah asset produktif dalam bentuk pembiayaan. Semakin banyak dana yang bisa disalurkan dalam pembiayaan berarti semakin tinggi earning asset, artinya dana yang dihimpun dari masyarakat dapat disalurkan dalam bentuk pembiayaan produktif sehingga tidak banyak asset yang menganggur. Pembiayaan bermasalah adalah suatu penyaluran dana yang dilakukan oleh lembaga pembiayaan seperti bank syariah yang dalam pelaksanaan pembayaran pembiayaan oleh nasabah. Dari kegiatan pembiayaan ini, semakin banyak dana yang disalurkan maka potensi timbulnya risiko pun semakin besar. Hal ini karena pembiayaan merupakan salah satu aktivitas perbankan yang memiliki risiko disebabkan oleh adanya ketidak mampuan peminjam untuk melunasi kewajibannya kepada pihak bank. Besarnya risiko pembiayaan ditunjukkan dalam rasio Non Performing Finance (NPF). Tingginya NPF menunjukkan banyaknya jumlah peminjam yang tidak dapat mengembalikan pinjaman sesuai dengan perjanjian awal yang telah disepakati bersama antara bank dengan peminjam.

Pembiayaan dengan kolektibilitas kurang lancar, diragukan, dan macet termasuk dalam NPF. Semakin besar NPF menunjukkan semakin tinggi tingkat pembiayaan bermasalah, sehingga mengakibatkan turunnya pendapatan yang berpengaruh pada kinerja, tingkat kesehatan dan kelangsungan bank. Pembiayaan bermasalah atau macet memberikan dampak yang kurang baik bagi Negara, masyarakat, dan bank. Bahaya atas pembiayaan macet yakni tidak terbayarnya kembali pembiayaan yang diberikan, baik sebagian atau seluruhnya, (Syafi'I, 2001).

Semakin besar pembiayaan macet yang dihadapi oleh bank, maka menurun pula tingkat kesehatan bank mempengaruhi tingkat Likuiditas dan Solvabilitas, yang dapat mempengaruhi kepercayaan para penitip dana atau para nasabah. Demikian pula, semakin besar jumlah pembiayaan bermasalah, maka semakin besar jumlah dana cadangan yang harus disediakan oleh bank tetapi semakin besar pula tanggungan bank untuk mengadakan dana cadangan tersebut. Adapun dampak yang ditimbulkan oleh pembiayaan bermasalah tersebut menguatkan keharusan bank untuk berusaha mengupayakan penanggulangan ataupun pencegahan bahaya yang mungkin timbul akibat pembiayaan bermasalah tersebut.

Analisis pembiayaan merupakan suatu proses analisis yang dilakukan oleh bank syariah untuk menilai suatu permohonan pembiayaan yang telah diajukan oleh calon nasabah. Dengan melakukan analisis permohonan pembiayaan, bank syariah akan memperoleh keyakinan bahwa proyek yang akan dibiayai layak (feasible). Bank melakukan analisis pembiayaan dengan tujuan untuk mencegah secara dini kemungkinan terjadinya default oleh nasabah. Analisis pembiayaan merupakan salah satu faktor yang sangat penting bagi bank syariah dalam mengambil keputusan untuk menyetujui atau menolak permohonan pembiayaan, dengan analisis yang baik akan menghasilkan keputusan yang tepat. Analisis pembiayaan merupakan salah satu faktor yang dapat digunakan sebagai acuan bagi bank syariah untuk meyakini kelayakan atas permohonan pembiayaan nasabah.

Berkaitan dengan pembiayaan di bank syariah, dalam melakukan penilaian permohonan pembiayaan bank syariah bagian marketing harus memperhatikan beberapa prinsip dan analisis utama yang berkaitan dengan kondisi secara keseluruhan calon nasabah, sehingga bisa mengurangi tingkat pembiayaan bermasalah calon nasabah di dunia perbankan syariah. Adapun prinsip dasar yang perlu dilakukan sebelum memutuskan permohonan 
Amiruddin K. Kelayakan Nasabah Nasabah Dalam Pemberian Pembiayaan ...

pembiayaan yang diajukan oleh calon nasabah antara lain dikenal dengan prinsip " $5 C$ " dan analisis " $6 A$ "; penerapan prinsip dasar dalam pemberian pembiayaan serta analisis yang mendalam terhadap calon nasabah, perlu dilakukan oleh bank syariah agar bank tidak salah memilih dalam menyalurkan dananya sehingga dana yang disalurkan kepada nasabah dapat terbayar kembali sesuai dengan jangka waktu yang diperjanjikan. Maka tujuan utama analisis pembiayaan adalah menilai mutu permintaan pembiayaan baru yang diajukan oleh calon debitur ataupun permintaan pembiayaan terhadap pembiayaan yang sudah pernah diberikan yang diajukan oleh debitur yang lama. Sehingga dengan adanya analisis tersebut maka akan meminimalisir adanya pembiayaan yang bermasalah, (Ismail, 2010).

\section{LANDASAN TEORI}

Kasmir (2012) memberikan penjelasan mengenai beberapa prinsip dasar yang perlu dilakukan sebelum memutuskan permohonan pembiayaan yang diajukan oleh calon nasabah anatara lain sebagai berikut:

\section{Character}

Menggambarkan tentang sifat atau watak nasabah. Analisis ini untuk mengetahui sifat atau watak seorang nasabah pemohon kredit, apakah memiliki watak atau sifat yang bertanggung jawab terhadap kredit yang diambilnya. Dari watak atau sifat ini, akan terlihat kemauan nasabah untuk membayar dalam kondisi sesulit apapun. Namun, sebaliknya jika nasabah tidak memiliki sifat yang mau membayar, nasabah akan berusaha mengelak untuk membayar dengan berbagai alasan tentunya. Watak atau sifat ini akan dapat dilihat dari masa lalu nasabah melalui pengamatan, pengalaman, riwayat hidup, maupun hasil wawancara dengan nasabah. Cara yang perlu dilakukan oleh bank untuk mengetahui character calon nasabah antara lain:

a) BI Checking

Bank dapat melakukan penelitian dengan melakukan BI Cheking, yaitu melakukan penelitian terhadap calon nasabah dengan melihat data nasabah melalui computer yang online dengan bank Indonesia. BI Cheking dapat digunakan oleh bank untuk mengetahui dengan jelas oleh nasabahnya, baik kualitas pembiayaan calon nasabah bila telah menjadi debitur lain.

b) Informasi dari pihak lain

Dalam hal calon nasabah masih belum memilki pinjaman di bank lain, maka cara yang efektif ditempuh yaitu dengan meneliti calon nasabah melalui pihak-pihak lain yang mengenal dengan baik calon nasabah. Misalnya, mencari informasi tentang karakter calon nasabah melalui tetangga, teman kerja, atasan langsung, dan rekan usahanya. Karakter merupakan faktor yang sangat penting dalam evaluasi calon nasabah.

\section{Capacity}

Yaitu analisis yang digunakan untuk melihat kemampuan keuangan nasabah dalam memenuhi kewajibannya sesuai jangka waktu pembiayaan. Kemampuan ini dapat dilihat dari penghasilan pribadi untuk pembiayaan konsumtif dan usaha yang dibiayai untuk pembiayaan perdagangan atau produktif. Kemampuan ini penting untuk dinilai agar tidak mengalami kerugian. Untuk menilai kemampuan nasabah dapat dinilai dari dokumen yang dimiliki.

Beberapa cara yang dapat ditempuh dalam mengetahui kemampuan keuangan calon nasabah antara lain (Ikawati, 2012);

a) Melihat Laporan Keuangan

Dalam laporan keuangan calon nasabah, maka akan dapat diketahui sumber dananya, dengan melihat laporan arus kas. Didalam laporan arus kas secara keseluruhan dapat diketahui kondisi keuangan secara tunai dari calon nasabah, dengan membandingkan antar sumber dana yang diperoleh dan penggunaan dana. 
b) Memeriksa Slip Gaji dan Rekening Tabungan

Cara lain yang dapat ditempuh oleh bank syariah, bila calon nasabah pegawai, maka bank dapat meminta fotocopy slip gaji tiga bulan terakhir dan didukung oleh rekening tabungan sekurang-kurangnya untuk tiga bulan terakhir. Dari data slip gaji dan fotocopy rekening tabungan tiga bulan terakhir, maka akan dapat di analisis tentang sumber dana dan penggunaan dana calon nasabah. Data keuangan digunakan sebagai asumsi dasar tentang kondisi keuangan calon nasabah setelah mendapat pembiayaan dari bank syariah.

c) Survey ke Lokasi Usaha Calon Nasabah

Survey ini dilakukan untuk mengetahui usaha calon nasabah dengan melakukan pengamatan secara langsung.

3. Capital

Yaitu untuk menilai modal yang dimiliki oleh nasabah untuk membiayai kredit. Hal ini penting karena bank tidak akan membiayai kredit tersebut 100\%. Artinya harus ada modal dari nasabah. Tujuannya adalah jika nasabah juga ikut memiliki modal yang ditanamkan pada kegiatan tersebut, nasabah juga akan merasa memiliki sehingga termotivasi untuk bekerja sungguh-sungguh agar usaha tersebut berhasil, dan mampu untuk membayar kewajiban kreditnya. Cara yang ditempuh oleh bank untuk mengetahui capital antara lain:

a) Laporan Keuangan Calon Nasabah

Dalam hal calon nasabah adalah perusahaan, maka struktur modal ini penting untuk menilai tingkat debt to equity ratio. Perusahaan dianggap kuat dalam menghadapi berbagai macam risiko apabila jumlah modal sendiri yang dimiliki cukup besar. Analisis rasio keuangan dapat dilakukan oleh bank untuk dapat mengetahui modal perusahaan. Analisis rasio keuangan ini dilakukan apabila calon nasabah merupakan perusahaan.

b) Uang Muka

Uang muka yang dibayakarkan dalam memperoleh pembiayaan. Dalam hal calon nasabah adalah perorangan, dan tujuan penggunaannya jelas, misalnya pembiayaan untuk pembelian rumah, maka analisis capital dapat diartikan sebagai jumlah uang muka yang dibayarkan oleh calon nasabah kepada pengembang atau uang muka yang telah disiapkan. Semakin besar uang muka yang dibayarkan oleh calon nasabah untuk membeli rumah, semakin meyakinkan bagi bank bahwa pembiayaan yang akan disalurkan kemungkinan akan lancar.

4. Collateral

Merupakan agunan yang diberikan oleh calon nasabah atas pembiayaan yang diajukan. Agunan merupakan sumber pembayaran kedua. Dalam hal nasabah tidak dapat membayar angsurannya, maka bank syariah dapat melakukan penjualan terhadap agunan. Hasil penjualan agunan digunakan sebagai sumber pembayaran kedua untuk melunasi pembiayaannya. Bank tidak akan memberikan pembiayaan yang melebihi dari nilai agunan, kecuali untuk pembiayaan tertentu yang dijamin pembayarannya oleh pihak tertentu. Dalam analisis agunan, faktor yang sangat penting dan harus diperhatikan adalah purnajual dari agunan yang diserahkan kepada bank. Bank syariah perlu mengetahui minat pasar terhadap agunan yang diserahkan oleh calon nasabah. Bila agunan merupakan barang yang diminati oleh banyak orang, maka bank yakin bahwa agunan yang diserahkan calon nasabah mudah diperjualbelikan. Pembiayaan yang ditutup oleh agunan yang purnajualnya bagus, risikonya rendah.

Secara perinci pertimbangan atas Collateral dikenal dengan $M A S T$ yaitu sebagai berikut:

a) Marketability

Agunan yang diterima oleh bank haruslah agunan yang mudah diperjualbelikan dengan harga yang menarik dan meningkat dari waktu ke waktu.

b) Ascertainability of value

Agunan yang diterima memiliki standar harga yang lebih pasti. 
Amiruddin K. Kelayakan Nasabah Nasabah Dalam Pemberian Pembiayaan ...

c) Stability of value

Agunan yang diserahkan oleh bank memiliki harga yang stabil, sehingga ketika agunan dijual, maka hasil penjualan bisa meng-cover kewajiban debitur.

d) Transferability

Agunan yang diserahkan bank mudah dipindahtangankan dan mudah dipindahkan dari satu tempat ke tempat yang lainnya.

\section{Condition Of Economic}

Dalam menilai kredit hendaknya juga dinilai kondisi ekonomi sekarang dan untuk di masa yang akan datang sesuai sektor masing-masing. Kondisi yang akan dinilai terutama kondisi ekonomi saat ini, apakah layak untuk membiayai kredit untuk sektor tertentu. Misalnya kondisi produksi tanaman tertentu sedang membludak di pasaran (jenuh). Maka, kredit untuk sektor tersebut sebaliknya dikurangi. Kondisi lainnya yang harus diperhatikan adalah kondisi lingkungan sekitar, misalnya kondisi keamanan dan kondisi social masyarakat. sebagai berikut:

Sedangkan penilaian pembiayaan dengan menggunakan metode analisis $7 \mathrm{P}$ adalah

1. Personality, yaitu menilai nasabah dari segi kepribadiannya atau tingkah lakunya sehari-hari maupun masa lalunya. Personality juga mencakup sikap, emosi, tingkah laku dan tindakan nasabah dalam menghadapi masalah.

2. Party, yaitu mengklasifikasikan nasabah ke dalam klasifikasi tertentu atau golongangolongan tertentu berdasarkan modal, loyalitas serta karakternya. Sehingga nasabah dapat digolongkan ke dalam golongan tertentu akan mendapatkan fasilitas yang berbeda dengan bank.

3. Purpose, yaitu mengetahui tujuan nasabah dalam mengambil pembiayaan, termasuk jenis pembiayaan yang diinginkan nasabah. Tujuan pengambilan pembiayaan dapat bermacam-macam. Sebagai contoh apakah untuk modal kerja atau investasi, konsumtif, atau produktif dan lain sebagainya.

4. Prospect, yaitu untuk menilai usaha nasabah di masa yang akan datang apakah menguntungkan atau tidak, memiliki prospek atau tidak. Hal ini penting untuk mengingat jika suatu fasilitas pembiayaan yang dibiayai tanpa mempunyai prospek, bukan hanya bank yang dirugikan, tetapi juga nasabah.

5. Payment, merupakan ukuran bagaimana cara nasabah mengembalikan kredit yang telah diambil atau dari sumber mana saja dana untuk pengembalian kredit. Semakin banyak sumber penghasilan debitur maka akan semakin baik. Jika salah satu usahanya merugi maka akan dapat ditutupi oleh usaha lainnya.

6. Profitability, untuk menganalisis bagaimana kemampuan nasabah dalam mencari nasabah. Protability diukur dari satu period ke periode lainnya apakah akan tetap sama atau semakin meningkat, apalagi dengan tambahan kredit yang akan diperolehannya.

7. Protection, tujuannya adalah bagaimana menjaga agar usaha dan jaminan mendapatkan perlindungan. Perlindungan dapat berupa jaminan barang atau orang atau jaminan asuransi kredit dengan jaminan: kredit yang diberikan dengan suatu jaminan. Jaminan tersebut dapat berbentuk barang berwujud atau bukan berwujud atau jaminan orang.

Di samping menggunakan 5C dan 7P, maka penilaian suatu kelayakan pembiayaan dapat dilakukan dengan menilai seluruh aspek yang ada. Penilaian seluruh aspek yang dikenal dengan nama studi kelayakan usaha. Penilaian dengan modal ini biasanya digunakan untuk proyek-proyek yang bernilai besar dan dalam jangka panjang. Aspek-aspek yang dinilai terdiri dari beberapa yaitu sebagai berikut (Abdullah, 2014);

1. Aspek Hukum

Analisis aspek hukum perlu dilakukan oleh bank syariah untuk evaluasi terhadap legalitas calon nasabah. Di dalam akad pembiayaan, terdapat dua pihak yang berserikat, yaitu bank syariah sebagai pihak yang menginvestasikan modal dan pihak nasabah yang mendapat 
kepercayaan untuk menjalankan usahanya. Kedua pihak mempunyai hak dan kewajiban masing-masing, oleh karena itu perlu dilandasi oleh dasar-dasar hukum secara formal sesuai dengan prinsip syariah dan undang-undang yang berlaku. Nasabah pembiayaan dapat digolongkan menjadi tiga kelompok, antara lain:

a) Nasabah perorangan (individu)

Adalah permohonan pembiayaan yang diajukan oleh seseorang atas nama pribadi. Pada umumnya tujuan mengajukan pembiayaan adalah untuk memenuhi kebutuhan sendiri. Bank syariah akan mengevaluasi aspek-aspek legalitas yang dimiliki nasabah perorangan tersebut, misalnya KTP, KK, Surat Nikah, bukti kepemilikan atau asset yang akan diagungkan, dan aspek legalitas lainnya yang diperlukan.

b) Nasabah merupakan bentuk usaha yang bukan badan hukum.

Nasabah merupakan bentuk usaha bukan badan hukum antara lain, CV, UD, dan firma. Bank akan melihat pemilik serta pihak yang berhak melakukan perjanjian dengan pihak ketiga, bila nasabah bentuk usaha yang bukan badan hukum. Hal ini dapat dilihat pada akta pendiriannya, izin usaha yang dimiliki, izin domisili, dan NPWP.

c) Nasabah merupakan bentuk usaha yang badan hukum

Yang termasuk dalam kelompok ini antara lain; perseroan terbatas, pesero, koperasi, dan yayasan. Peseroan terbatas, persero, dan yayasan perlu dilihat legalitas yang dimiliki antara lain: Akta pendirian, apakah dibuat secara notariil. Akta tersebut telah disahkan oleh Kementrian Hukum dan HAM. Izin-izin usaha yang terkait dengan jenis usaha yang calon nasabah, misalnya SIUP, TDP, TDUP, HO, izin Domisili, dan perizinan lainnya. NPWP dan lain-lain.

Dengan melakukan analisis terhadap aspek hukum, maka bank syariah akan mendapat informasi tentang pihak yang berhak melakukan penandatanganan dalam perjanjian serta hak dan kewenangannya. Faktor sangat penting dalam analisis hukum adalah keyakinan bank syariah bahwa setelah memberikan pembiayaan, maka legalitasnya kuat, sehingga bank aman bila terjadi risiko. Pada saat terjadi sengketa atas pembiayaan, maka bank syariah dapat memenangkan sengketa.

2. Aspek Pemasaran

Aspek pemasaran merupakan aspek yang sangat penting untuk dianalisis lebih mendalam karena hal ini terkait dengan aktivitas pemasaran produk calon nasabah. Bank syariah dapat mengetahui sejauh mana produk yang dihasilkan oleh calon debitur diterima oleh pasar dan berapa lama produknya dapat bertahan dan bersaing di pasar.

Analisis pemasaran diperlukan oleh bank untuk menghitung kemungkinan penjualan produk setiap tahun. Kemudian bank syariah akan dapat memperkirakan berapa jumlah uang yang akan diterima atas hasil penjualan produk. Dengan mengetahui hasil penjualan, maka bank akan dapat menghitung arus kas masuk dan arus kas keluar, sebagai dasar perhitungan kemampuan calon nasabah untuk membayar angsuran.

Secara perinci, aspek pemasaran yang perlu dianalisis antara lain sebagai berikut:

a) Produk yang dipasarkan

Bank melakukan analisis terhadap produk yang ditawarkan oleh calon nasabah yang ada dipasar, untuk mengetahui seberapa besar produk yang dipasarkan tergolong produk yang diminati oleh konsumen.

b) Pangsa pasar

Bank melakukan analisis terhadap pangsa pasar produk yang ditawarkan oleh nasabah, dengan tujuan untuk mengetahui seberapa besar pangsa pasarnya dan mengetahui pangsa pasar yang dapat diambil oleh perusahaan calon nasabah.

c) Pesaing

Analisis pesaing dilakukan untuk mengetahui seberapa kuat para pesaing produk calon nasabah, dan kemungkinan produknya dapat memenangkan persaingan. Bank syariah 
juga perlu yakin bahwa nasabah mampu melakukan inovasi pasar, sehingga dapat tetap bertahan atau bahkan memenangkan persaingan, minimal dalam kurun waktu tertentu sesuai dengan jangka waktu pembiayaan.

d) Strategi pemasaran

Bank perlu mengetahui strategi pemasaran yang diterapkan oleh perusahaan dalam merebut pasar atau bertahan pada pasar tertentu selama masa pembiayaan.

3. Aspek Teknis

Merupakan analisis yang dilakukan bank syariah dengan tujuan untuk mengetahui fisik dan lingkungan usaha perusahaan calon nasabah serta proses produksi. Dengan menganilisis aspek tekhnis bank syariah dapat menyimpulkan apakah perusahaan calon nasabah menjalankan aktivitas produksinya secara efisien.

Prosedur pemberian pembiayaan merupakan tahap-tahap yang harus dilakukan sebelum sesuatu pembiayaan diputuskan untuk diberikan. Dengan tujuan untuk mempermudah bank dalam menilai kelayakan suatu permohonan pembiayaan. Prosedur pemberian pembiayaan dibedakan menjadi dua yaitu untuk pembiayaan perorangan dan pembiayaan oleh suatu badan hukum, dan jika dilihat dari segi tujuannya yaitu pembiayaan konsumtif dan pembiayaan produktif.

\section{METODE PENELITIAN}

Dalam penelitian ini menggunakan metode penelitian kualitatif deskriptif. Penelitian ini dilaksanakan di Bank Pembiayaan Rakyat Syariah IMB Makassar. Untuk memperoleh informasi dan data-data yang dibutuhkan. Data primer diperoleh dari hasil wawancara secara langsung dengan pihak Bank Pembiayaan Rakyat Syariah IMB Makassar. Bentuk data wawancara yang dimaksud berupa catatan hasil wawancara yaitu catatan lapangan serta keterangan dari pegawai bank. Data sekunder dari dokumen-dokemen Bank yang relevan dengan fokus penelitian ini.

Analisis data yang digunakan dalam penelitian ini adalah deskriptif kualitatif. Deskriptif kualitatif bertujuan untuk mendeskripsikan suatu peristiwa atau kejadian yang saat ini berlaku. Dengan kata lain penelitian ini tidak mencari tahu menjelaskan hubungan, tetapi hanya berbentuk narasi yang bertujuan untuk mengumpulkan informasi aktual secara rinci yang menjelaskan tentang analisis kelayakan pemberian pembiayaan pada Bank Pembiayaan Rakyat Syariah IMB Makassar.

Pengolahan data dilakukan setelah data diperoleh dari hasil wawancara, dokumentasi, dan observasi langkah-langkah yang dilakukan, yaitu, (Lawrence, 2013).

1. Peneliti memulai mengorganisasikan semua data yang telah dikumpulkan.

2. Membaca data secara keseluruhan dan membuat catatan pinggir mengenai data yang dianggap penting kemudian melakukan pengkodean data

3. Menemukan dan mengelompokkan pernyataan yang dirasakan oleh responden dengan melakukan horizonaliting yaitu setiap pernyataan yang tidak relevan dengan topik dan pertanyaan maupun pernyataan yang bersifat retitif atau tumpang tindih

4. Reduksi data (data Reduction), memilah, memusatkan, dan menyederhanakan data yang diperoleh dari penelitian yang masih mentah yang muncul dari catatan-catatan tertulis dilapangan.

5. Penyajian data, yaitu dengan merangkai dan menyusun informasi dalam bentuk satu kesatuan, selektif dan dipahami.

Perumusan dalam simpulan, yakni dengan melakukan tinjauan ulang di lapangan untuk menguji kebenaran dan validitas makna yang muncul disana. Hasil yang diperoleh diinterpretasikan, kemudian disajikan secara naratif. 


\section{AL-MASHRAFIYAH: Jurnal Ekonomi, Keuangan, dan Perbankan Syariah}

Volume 2, Nomor 2, Oktober 2018

\section{HASIL DAN PEMBAHASAN}

\section{A. Analisis Bank Syariah Terhadap Kelayakan Nasabah dalam Pemberian Pembiayaan}

Pembiayaan merupakan salah satu produk yang dimiliki oleh suatu perbankan dalam menjalankan kegiatannya. Setiap perbankan memiliki standarnya masing-masing dalam menentukan kelayakan nasabah untuk diberi pembiayaan. Dengan demikian bank harus menentukan kadar risiko yang akan di pikulnya dalam setiap kasus dan berapa jumlah pembiayaan yang dapat disetujui dengan mempertimbangkan risiko. Risiko pembiayaan mempunyai dimensi kualitatif dan kuantitatif. Tetapi dimensi kualitatif itu pada umumnya lebih sulit untuk dinilai.

Yulianus Sumule, yang berperan sebagai analisis Pembiayaan pada PT. Bank Pembiayaan Rakyat Syariah Investama Mega Bakti Makassar, mengatakan bahwa dalam menganalisis seorang nasabah/anggota yang pantas dan sesuai untuk menerima sebuah pembiayaan dari Bank Pembiayaan Rakyat Syariah IMB Makassar, maka kami melakukan sebuah analisis dengan menggunakan prinsip pembiayaan yaitu $5 C$.

1. Character

Untuk memperoleh gambaran tentang karakter nasabah dapat ditempuh upaya-upaya sebagai berikut:

a) Meneliti riwayat hidup dari calon mitra,

b) Meneliti reputasi di tempat uasaha calon mitra,

c) Meminta informasi dari bank ke bank yang pernah memberikan fasilitas pembiayaan,

d) Mencari informasi kehidupan calon nasabah dari lingkungan tempat tinggal.

2. Capacity

Untuk melihat kemampuan nasabah dalam membayar kewajibannya yang dihubungkan dengan kemampuannya mengelola bisnis serta kemampuannya mencari laba. Semakin banyak pendapatannya maka semakin besar kemampuannya dalam mengembalikan pinjamannya. Kita bisa menilai kapasity dari calon nasabah dengan cara:

a) Menilai kekayaan nasabah, dengan cara melihat seberapa besar asset yang dimiliki nasabah,

b) Melihat perkembangan usaha yang dilakukan oleh nasabah,

c) Melihat laporan keuangan dari usaha yang dilakukan oleh nasabah.

3. Capital

Modal yang dimaksud di sini adalah ketersediaan modal awal nasabah sebelum mengajukan pembiayaan. Poin capital ini tidak terlalu dipertimbangkan oleh Bank Pembiayaan Rakyat Syariah IMB Makassar dibandingkan dengan karakter, kapasitas dan agunan/jaminan. Akan tetapi poin ini masih dinilai juga demi keamanan dan kehati-hatian Bank Pembiayaan Rakyat Syariah IMB Makassar dalam menyalurkan pembiayaan.

4. Collateral

Menilai dan menganalisis agunan yang diajukan oleh calon nasabah ke Bank Pembiayaan Rakyat Syariah IMB Makassar. Nilai dari jaminan diharuskan jumlahnya tinggi dibandingkan dengan pinjamannya. Pinjaman diharuskan sebesar 75\% dari nilai jaminan yang diagunkan. Menilai juga keabsahan atau keaslian dari jaminan, yang akan bisa dipergunakan secepat mungkin apabila terjadi suatu masalah.

2. Condition of Economy

Melihat kondisi lingkungan saat pemberian pembiayaan baik kondisi ekonomi yang terjadi maupun politik. Sehingga dibutuhkan kondisi stabil dalam pengukuran dana pembiayaan. Dan apabila dalam kondisi yang tidak stabil pembiayaan tetap diberikan maka perlu dilihat prospek usaha tersebut di masa yang akan datang. 
Amiruddin K. Kelayakan Nasabah Nasabah Dalam Pemberian Pembiayaan ...

Prinsip 5C ini merupakan prinsip dasar yang dipakai oleh Bank Pembiayaan Rakyat Syariah Investama Mega Bakti Makassar. Selain prinsip 5C ini yang digunakan oleh pihak bank, adapun prinsip lain yaitu prinsip FAST, yakni Fathanah, Amanah, Shiddiq, Tabligh.

1. Fathanah, artinya cakap dan cerdas dalam menganalisis permohonan nasabah. Dalam hal ini meliputi dua unsure yakni:

a) Fathanah dalam administrasi atau manajemen dagang, artinya hal-hal yang berkenaan dengan aktivitas harus dicatat atau dibukukan secara rapi.

b) Fathanah dalam hal menangkap selera pembeli yang berkaitan dengan barang maupun harta.

2. Amanah, artinya tidak mengurangi apa-apa yang tidak boleh dikurangi dan sebaliknya tidak boleh ditambah. Dalam hal ini termasuk juga menambah harga jual yang telah ditentukan atas pengetahuan pemilik barang. Sifat amanah yang ada pada nasabah akan memberikan dampak positif bagi diri pelaku usaha yang dijalanimya. Sehingga usahanya akan semakin berkembang dan bank yang akan memberikan pembiayaan merasa yakin untuk memberikan pembiayaan.

3. Shiddiq, artinya benar dalam perkataan dan benar pula dalam perbuatan, pebisnis dilarang melakukan hal yang tidak baik. Apabila shiddiq dilakukan oleh pelaku bisnis maka praktek bisnis jahiliyah tidak terjadi perbuatan penipuan.

4. Tabligh, artinya komunikatif dan argumentatif. Yaitu orang yang memiliki sifat tabligh akan menyampaikan sesuatu dengan benar (berbobot) dan dengan tutur kata yang tepat.

Setalah pihak bank menganalisis permohonan nasabah dengan menggunakan konsep $5 C$ dan konsep FAST, pihak bank tidak langsung pembiayaannya diterima, melainkan pihak analisis menyerahkan ke bagian DPS untuk menganalisis ulang, apakah nasabah layak atau tidak diberikan pembiayaan.

Begitu pula yang dikatakan oleh ibu Yani selaku analisis pembiayaan, mengatakan bahwa pembiayaan yang dominan diajukan oleh calon nasabah yakni pembiayaan KPR dengan akad Murabahah. Adapun skema pembiayaan dengan akad Murabahah yaitu:

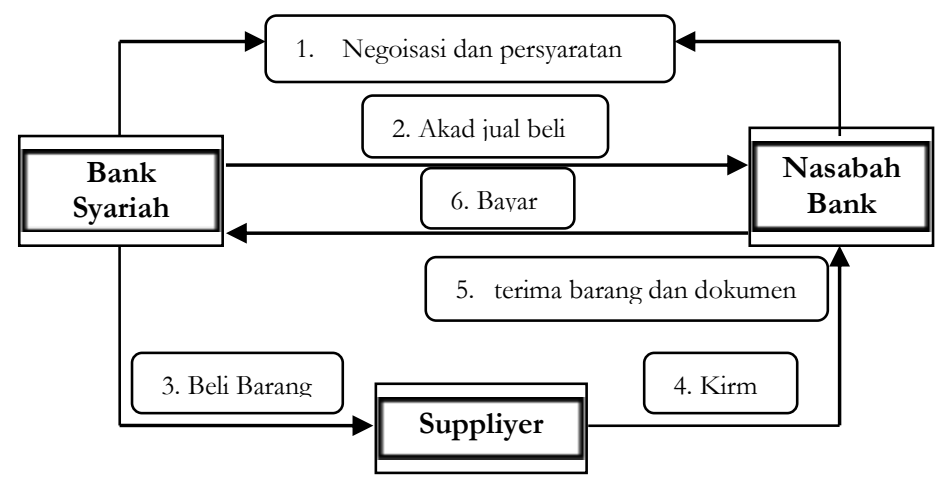

Sumber: Bank Pembiayaan Rakyat Syariah IMB Makassar

Kredit Kepemilikan Rumah merupakan pembiayaan Murabahah yang bersifat konsumtif. Dimana bank menyediakan pinjaman dana untuk membeli rumah, tanah kavling atau untuk merenovasi rumah yang diperlukan calon penerima kredit, untuk dibayar kembali saat jatuh tempo dengan cara cicilan. Pada saat akad, pembiayaan KPR diakui pada saat pencairannya sebesar pokok pembiayaan yang diberikan dan keuntungan yang disepakati. Keuntungan ini disebut margin yang merupakan pendapatan bank, dimana besarnya margin ditetapkan berdasarkan kesepakatan antara nasabah dan Bank Pembiayaan Rakyat Syariah IMB Makassar. Adapun marginnya yaitu 1-5 tahun sebesar 8,5\%, 6-10 tahun sebesar 9,5\% dan 1115 tahun sebesar $10,5 \%$. 
Fatmasari (2013), dalam artikelnya menyatakan bahwa, Pembiayaan kepemilikan rumah umumnya menggunakan akad Murabahah (jual-beli). Akad Murabahah (jual-beli) yaitu akad jual beli barang, dalam hal ini adalah rumah, dimana si penjual menyatakan harga perolehannya dan marjin yang diinginkan pada saat penjualan kepada si pembeli atas kesepakatan bersama. Akad yang lainnya adalah pembiayaan kepemilikan rumah dengan akad Ijarah Muntabiyah Bittamlik (IMBT) yang pada prakteknya masih jarang digunakan, merupakan pembiayaan yang menggunakan akad sewa-beli dimana nasabah menyewa barang atau dalam hal ini rumah yang pada akhir masa sewanya akan terjadi pengalihan hak kepemilikan rumah. Perpindahan kepemilikan atas rumah dengan akad ini dapat dilaksanakan dengan beberapa cara yaitu dengan hibah atau jual-beli.

Dalam praktek perbankan syari'ah, murababah selalu menggunakan jenis "al bay' bisaman ajil" atau "muajjll" jenis pembayaran secara tangguh atau cicilan. Jadi, murabahah merupakan transaksi jual beli, di mana bank bertindak sebagai penjual dan nasabah sebagai pembeli. Akad jenis ini adalah salah satu bentuk akad bisnis yang mencari keuntungan bersifat pasti (certainly return) dan telah diketahui dimuka (pre-determiner return). Murabahah sendiri merupakan penjualan sesuatu barang dengan harga asal dengan tambahan keuntungan sejumlah yang disepakati bersama (IBMT, cit Haris, 2007). Dengan sistem murabahab yang diterapkan dalam pembiayaan KPR ini berarti pihak bank syari'ah harus memberitahukan harga perolehan atau harga asal rumah yang dibeli dari developer kepada nasabah KPR Syari'ah dan menentukan suatu tingkat keuntungan (Profit Margin) sebagai tambahan (Antonio cit Haris, 2007).

Menurut Muh. Rifki Erdiansyah, jangka waktu pengembalian pinjaman sudah ditetapkan oleh pihak bank, akan tetapi pihak bank memberikan wewenang kepada pihak nasabah untuk menentukan jangka waktunya sendiri yang jelas tidak keluar dari jangka waktu yang ditetapkan oleh pihak bank. Muh. Rifki mengatakan bahwa kita disini memberikan kelonggaran kepada nasabah, agar nasabah bisa mengembalikan pinjaman yang dia ambil sesuai jangka waktu yang disepakati.

Berkenaan dengan tingkat kemudahan yang diberikan pada pembiayaan murabahah, Rohmi (2015), dari hasil penelitiannya menyatakan bahwa dalam implementasinya, terdapat perbedaan di beberapa bank syariah, yaitu menggunakan akad murabahah dan musyarakah mutanaqishah. Pada tahun 2008, Dewan Syariah Nasional menerbitkan fatwa mengenai akad musyarakah mutanaqisah dalam pembiayaan kepemilikan rumah. Namun akad tersebut masih belum diterapkan oleh seluruh perbankan syariah. Pada tahun 2012 Bank Indonesia mengeluarkan surat edaran kepada seluruh Bank Syariah dan Unit Usaha Syariah yang semakin melegitimasi penerapan akad musyarakah mutanaqisah di perbankan syariah. Akad musyarakah mutanaqisah dalam produk KPR akan mempermudah nasabah dalam pembiayaan KPR tersebut. Keunggulan akad musyarakah mutanaqisah bagi nasabah adalah jangka waktu pembiayaan yang lebih lama dan angsuran yang relatif lebih murah.

Secara prinsip keduanya dibenarkan dalam menjalankan produk KPR. Haris (2007) dalam Artikelnya menyatakan bahwa, Bank syari'ah memadukan dan menggali skim-skim transaksi yang dibolehkan dalam Islam dengan operasional KPR perbankan konvensional. Adapun skim yang banyak digunakan oleh perbankan syari'ah di Indonesia dalam menjalankan produk pembiayaan KPR adalah skim murabahah, istisna' dan ijaroh, khususnya ijarah muntabiya bi tamlik (IMBT).

Seperti yang dijelaskan bahwa di dalam menjalankan suatu usaha apapun tentu mengandung suatu tingkat kerugian. Risiko ini dapat saja terjadi akibat suatu musibah yang tidak dapat dielakkan seperti terkena bencana alam, tetapi risiko yang paling fatal adalah akibat nasabah yang mampu, tetapi tidak mau membayar kewajibannya. Adanya risiko kerugian di mana nasabah tidak sanggup lagi membayar semua keajibannya baik untuk sementara waktu atau selamanya harus segera diantisipasi oleh pihak bank. Ketidakmampuan nasabah dalam melunasi kreditnya, dapat ditutupi dengan suatu jaminan kredit. 
Fungsi jaminan kredit adalah untuk melindungi bank dari kerugian. Dengan adanya jaminan kredit dimana nilai jaminan biasanya melebihi nilai kredit, maka bank akan aman. Bank dapat mempergunakan atau menjual jaminan kredit untuk menutupi kredit apabila kredit yang diberikan macet. Maka dari itu jaminan disini sangat berpengaruh terhadap pemberian pembiayaan kepada nasabah, yang paling penting dalam jaminan kredit adalah mengikat nasabah untuk segera melunasi utang-utangnya.

Akan tetapi sepandai-pandainya analisis kredit dalam menganalisis setiap permohonan kredit, kemungkinan kredit tersebut mengalami kemacetan. Hal ini disebabkan oleh dua unsur sebagai berikut:

1. Dari pihak perbankan; artinya dalam melakukan analisisnya, pihak analisis kurang teliti, sehingga apa yang seharusnya terjadi tidak dapat diperkirakan sebelumnya. Hal ini dapat pula terjadi akibat kerja sama dari pihak analisis kredit dengan pihak debitur sehingga dengan melakukan analisisnya dilakukan secara subjektif.

2. Dari pihak nasabah; kemacetan kredit dapat dilakukan akibat dua hal yaitu: adanya unsur kesengajaan, artinya nasabah dengan sengaja bermaksud tidak membayar kewajibannya sehingga kredit yang diberikan macet. Adanya unsur tidak sengaja, artinya debitur mau membayar, tetapi tidak mampu. Sebagai contoh kredit yang dibiayai mengalami musibah seperti kebakaran, kena hama, kebanjiran, sehingga kemampuan untuk membayar kredit tidak ada.

Sejalan dengan pendapat yang dikemukakan oleh Fatimasari (2013), bahwa Apabila nasabah tidak dapat memenuhi piutang Murababah sesuai dengan yang diperjanjikan, bank berhak menggunakan denda kecuali jika dapat dibuktikan bahwa nasabah tidak mampu melunasi. Denda diterapkan bagi nasabah yang mampu menunda pembayaran. Denda tersebut didasarkan pada pendekatan ta'riryaitu untuk membuat nasabah disiplin terhadap kewajibannya. Besarnya denda sesuai dengan yang diperjanjikan dalam akad dan dana yang berasal dari denda diperuntukkan sebagai dana sosial (qardbul hasan).

Dalam kasus kredit macet ini pihak bank perlu melakukan penyelamatan, sehingga tidak akan menimbulkan kerugian. Penyelamatan yang dilakukan bisa dengan memberikan keringanan berupa jangka waktu pengembalian terutama bagi kredit yang mengalami musibah. Menurut Arifin Abdullah, penanganan pembiayaan yang dilakukan oleh pihak bank apabila terjadi pembiayaan bermasalah yakni:

1. Menjaga hubungan baik dengan nasabah, artinya ini bisa dilakukan jika nasabah/anggota masih memiliki prospek dan peluang yang baik bagi Bank Pembiayaan Rakyat Syariah IMB Makassar. Dengan demikian Bank Pembiayaan Rakyat Syariah Investama Mega Bakti, harus memiliki planning yang terarah. Dapat dilakukan dengan cara:

a) Restrukturisasi pembiayaan adalah upaya Bank Pembiayaan Rakyat Syariah Makassar melakukan perbaikan terhadap nasabah yang berpotensi atau mengalami kesulitan.

b) Pengembalian pokok, artinya dilakukan dengan cara pengalihan akad dari murabahah ke akad qardulhasan, ini bisa memperkecil angsuran dan meminimalkan terjadinya resiko.

c) Peringatan I, II, dan III, artinya peringatan diberikan secara bertahap mulai dari peringatan I, apabila peringatan I diabaikan maka peringatan II diberikan pula dan seterusnya sampai peringatan ke III. Baru pihak Bank Pembiayaan Rakyat Syariah IMB Makassar melakukan tindakan selanjutnya. Jangka antara surat peringatan I dengan surat peringatan lainnya adalah selama 3 bulan. Setelah terjadinya tunggakan bulan maka standar penyelesaian harus secara tegas melakukan tahapan-tahapan penagihan yang bersifat simultan. Adapun tahapannya yaitu: 
Tabel. 1. Tahapan-Tahapan Penagihan Nasabah Bank Pembiayaan Rakyat Syariah Investama IMB Makassar.

\begin{tabular}{|c|c|c|c|}
\hline Kolektibilitas & Tindakan & Pelaksana & Schedule \\
\hline Lancar & Kunjugan 2x sebulan & Staf Marketing & Minggu 2 dan 4 \\
\hline \multirow[b]{3}{*}{ Tunggakan 1} & Surat penagihan 1 & Kabag Marketing & Minggu 1 \\
\hline & Supervise & Kabag Marketing & Minggu 1 \\
\hline & $\begin{array}{l}\text { Satu bulan sebelum jatuh } \\
\text { tempo diberikan surat } \\
\text { pemberitahuan jatuh tempo. }\end{array}$ & Supord PYD & Minggu 1 \\
\hline \multirow{5}{*}{$\begin{array}{l}\text { Tunggakan } \\
\text { II }\end{array}$} & $\begin{array}{l}\text { Kunjungan minimal 2x } \\
\text { sebulan }\end{array}$ & Staff Marketing & Minggu 2 dan 4 \\
\hline & Surat tagih dan panggilan II & Support PYD & Minggu I \\
\hline & Supervise & Kabag Marketing & Minggu I \\
\hline & $\begin{array}{l}\text { Supervisi pusat } \\
\text { (administratif) }\end{array}$ & HOD Recoll & Minggu I \\
\hline & $\begin{array}{l}\text { Satu bulan sebelum jatuh } \\
\text { tempo diberikan surat } \\
\text { pemberitahuan jatuh tempo. }\end{array}$ & Super PYD & Minggu I \\
\hline \multirow{5}{*}{$\begin{array}{l}\text { Tunggakan } \\
\text { III }\end{array}$} & Kunjungan $2 \mathrm{x}$ sebulan & Staff Rmarketing & Minggu 2 dan 4 \\
\hline & Surat tagih dan panggilan III & Kabag marketing & Minggu 1 \\
\hline & Supervisi & Kabag marketing & Minggu 1 \\
\hline & $\begin{array}{l}\text { Supervisi Pusat } \\
\text { (lapangan) }\end{array}$ & HOD Recoll & Kondisional \\
\hline & $\begin{array}{l}\text { Satu bualn sebelum jatuh } \\
\text { tempo diberikan surat } \\
\text { pemberitahuan jatuh tempo. }\end{array}$ & Support PYD & Minggu 1 \\
\hline \multirow{6}{*}{$\begin{array}{l}\text { NPF } \\
\text { (tindakan } \\
\text { terhadap } \\
\text { anggota yang } \\
\text { bermasalah } \\
\text { setelah 1 } \\
\text { bulan } \\
\text { dilakukan } \\
\text { berdasarkan } \\
\text { keputusan } \\
\text { komite } \\
\text { cabang) }\end{array}$} & $\begin{array}{l}\text { Kunjungan minimal 2x } \\
\text { seminggu }\end{array}$ & Kabag Marketing & Minggu 1 \\
\hline & $\begin{array}{l}\text { Surat tagih dan surat } \\
\text { penagihan } 1\end{array}$ & Kabag Marketing & Kondisonal \\
\hline & Supervisi & Kabag Marketing & Kondisional \\
\hline & $\begin{array}{l}\text { Supervisi Pusat } \\
\text { (lapangan) }\end{array}$ & HOD Recoll & Kondisional \\
\hline & $\begin{array}{l}\text { Komite penyelamatan } \\
\text { pembiayaan bermasalah, } \\
\text { rencana tindakan }\end{array}$ & $\begin{array}{l}\text { Super PYD/ } \\
\text { Kabag Marketing }\end{array}$ & Kondisional \\
\hline & $\begin{array}{l}\text { Satu bulan sebelum jatuh } \\
\text { tempo diberikan surat } \\
\text { pemberitahuan jatuh tempo }\end{array}$ & $\begin{array}{l}\text { Support PYD. } \\
\text { Kabag Marketing }\end{array}$ & Minggu 1 \\
\hline
\end{tabular}

Sumber : Bank Pembiayaan Rakyat Syariah IMB Makassar, Tahun 2017

2. Penyitaan sampai penjualan barang agunan, artinya saat penyelesaian diatas sudah tidak bisa menyelesaikannya maka jalan terakhirnya adalah menjual/ melelang barang jaminan di lembaga keuangan, dan besarnya harga jual kemudian di konversikan kepada pihak bank.

3. Evaluasi, yaitu untuk melakukan pengawasan dan mengontrol penanganan pembiayaan yang dilakukan. 
Amiruddin K. Kelayakan Nasabah Nasabah Dalam Pemberian Pembiayaan ...

4. Hapus Buku, artinya apabila nasabah/anggota yang melakukan pembiayaan tidak diketahui informasi dan kabarnya, maka pihak Bank Pembiayaan Rakyat Syariah IMB Makassar berhak menghapus pembiayaan yang telah dilakukan.

\section{B. Dampak Kelayakan Terhadap Pemberian Pembiayaan Kepada Nasabah}

Dampak kelayakan sangatlah berpengaruh terhadap pemberian pembiayaan kepada nasabah. Dalam hal ini, kelayakan ini menjadi tolak ukur oleh pihak bank untuk memberikan kepastian layak atau tidaknya permohonan pembiayaan yang diajukan oleh pihak nasabah kepada pihak bank.

Menurut Sudri M. Aldiy, Komisaris PT. Bank Pembayaan Rakyat Syariah Investama Mega Bakti Makassar, adapun dampak kelayakan terhadap pemberian pembiayaan yakni kelayakan ini berdampak positif bagi pihak bank sebab dengan adanya kelayakan ini pihak bank dapat menilai setiap permohonan nasabah, apakah dia layak diberikan pembiayaan atau tidak. Maka dari itu sebelum pembiayaan diberikan maka bank harus merasa yakin bahwa pembiayaan yang akan diberikan benar-benar akan kembali. Keyakinan tersebut diperoleh dari hasil penilaian untuk mengetahui layak atau tidaknya diberikan pembiayaan. Penilaian ini dapat dilakukan dengan berbagai cara untuk mendapatkan keyakinan tentang nasabahnya, seperti melalui prosedur penilaian yang benar. Dalam melakukan penilaian kriteria-kriteria serta aspek penilaiannya tetap sama.

Biasanya kriteria penilaian yang harus dilakukan oleh bank, untuk mendapatkan nasabah yang benar-benar menguntungkan dilakukan dengan analisis $5 C$ dan $7 P$. kredit dengan penilaian 5C berisi penilaian tentang Character, Capacity, Capital, Condition, dan Collateral. Sedangkan untuk 7P kredit adalah Personality, Party, Purpose, Prospect, Payment, Profitability, dan Protection.

Menurut nasabah atas nama bapak Ridwan mengatakan bahwa Kelayakan ini memberikan dampak negatif pada pihak nasabah karena dengan adanya kelayakan ini maka untuk mendapatkan penambahan modal akan membutuhkan waktu yang cukup lama, disebabkan karena pihak bank akan menilai secara detail apakah permohonan yang diajukan ini layak diberikan pembiayaan atau tidak.

Berbeda dengan apa yang dikatakan oleh Bapak Hardiawan, dia mengatakan bahwa : adanya kelayakan ini karena permohonan yang kita ajukan benar-benar dianalisis oleh pihak bank sehingga mengurangi jumlah nasabah yang melakukan pembiayaan macet.

\section{PENUTUP}

Dari pembahasan yang telah dikemukakan pada bab sebelumnya, maka penulis dapat menarik suatu kesimpulan yakni:

1. Dalam menganalisis kelayakan nasabah untuk pemberian pembiayaan, PT. Bank Pembiayaan Rakyat Syariah IMB Makassar melakukan penilaian dengan menggunakan prinsip 5C, yaitu: Character, Capacity, Capital, Coleteral, Condition of Economy dan konsep FAST, yaitu Fathanah, Amanah, Shiddiq, Tabligh. Dengan tercapainya penilaian ini maka pihak bank dapat memutuskan layak atau tidaknya nasabah diberikan pembiayaan.

2. Adapun dampak kelayakan terhadap pemberian pembiayaan yakni untuk pihak bank akan berdampak positif sedangkan untuk pihak nasabah akan berdampak negatif.

a) Untuk pihak bank sendiri, kelayakan ini akan berdampak positif dalam pemberian pembiayaan karena dengan adanya kelayakan maka pihak bank dapat menganalisis secara detail permohonan nasabah, apakah dia layak atau tidak diberikan suatu pembiayaan. Dengan adanya kelayakan ini maka peluang untuk terjadinya pembiayaan macet akan kecil. 


\section{AL-MASHRAFIYAH: Jurnal Ekonomi, Keuangan, dan Perbankan Syariah Volume 2, Nomor 2, Oktober 2018}

b) Sedangkan untuk pihak nasabah, kelayakan ini akan berdampak negatif karena untuk mendapatkan modal secara cepat akan terhalang dengan adanya kelayakan ini. Karena untuk mendapatkan pembiayaan maka harus melalui analisis yang diterapkan oleh pihak bank, setelah analisis itu dapat tercapai maka pihak layak untuk diberikan pembiayaan. Oleh karena itu pihak nasabah untuk mendapatkan pembiayaan harus membutuhkan waktu yang relatif lama.

c) Untuk meminimalisirkan terjadinya pembiayaan bermasalah, hendaknya pihak Bank Pembiayaan Rakyat Syariah IMB Makassar lebih memperhatikan aspek kelayakan dalam penyaluran pembiayaan khususnya analisis $5 C$ dan FAST dan faktor-faktor teknis lainnya yang menjamin keamanan pembiayaan yang disalurkan.

\section{DAFTAR PUSTAKA}

Ascarya, (2013). Akad dan Produk Bank Syariah. Jakarta: PT Raja Grapindo Persada.

Burhan Bungin, (2012). Penelitian Kualitatif. Cetakan.II; Jakarta: Kencana.

Fatmasari, Nabila, (2013). "Analisis sistem pembiayaan kpr bank konvensional dan Pembiayaan kprs bank syariah (studi kasus bank btn dengan bank muamalat)." Jurnal Akuntansi Unesa 1.3

Haris, Helmi, (2007), "Pembiayaan kepemilikan rumah (sebuah inovasi pembiayaan perbankan syari'ah)." La_Riba 1.1 113-125.

Ikawaty, Vera (2012) Analisis Prosedur Pemberian Pembiayaan Musyarakah Pada Bank Syariah Mandiri Cabang Malang. Other thesis, University of Muhammadiyah Malang.

Ismail, (2011). Perbankan Syariah. Jakarta: Prenada Media Group

Kasmir, 2015. Bank Dan Lembaga Kenangan Lainnya. Jakarta: Rajawali Pers.

Moeloeng Lexy, (2008). Metode Penelitian Ilmiah. Bandung: PT. Remaja Resdakarya

Muhamad. Manajemen Dana Bank Syariah. Jakarta: Rajawali Pers. 2014.

Puspitasari, Maya, and Moses Laksono Singgih, (2011) "Analisa dan perbaikan sistem evaluasi kelayakan pengambilan Kredit di Bank Syariah X." Prosiding Seminar Nasional Manajemen Teknologi XIII.

Rohmi, Putri Kamilatur, (2015). "Implementasi Akad Musyarakah Mutanaqishah pada Pembiayaan Kepemilikan Rumah di Bank Muamalat Lumajang." Iqtishoduna: Jurnal Ekonomi Islam 4.1; 17-37

Syafi'I Muhammad, (2001). Bank Syariah dari Teori ke Praktek. Jakarta: Gema Insani Press

Thamrin Abdullah, Francis Tantri, Bank dan Lembaga Kenangan,(Jakarta: Rajawali Pers,2014), hal. 175 